\title{
A systematic examination of the relationships between CDOM and DOC in inland waters in China
}

\author{
Kaishan Song ${ }^{1}$, Ying Zhao ${ }^{1,2}$, Zhidan Wen ${ }^{1}$, Chong Fang ${ }^{1,2}$, and Yingxin Shang ${ }^{1}$ \\ ${ }^{1}$ Northeast Institute of Geography and Agroecology, CAS, Changchun, 130102, China \\ ${ }^{2}$ College of Resources and Environment, University of Chinese Academy of Sciences, Beijing, 100049, China \\ Correspondence to: Kaishan Song (songks@iga.ac.cn)
}

Received: 25 March 2017 - Discussion started: 4 April 2017

Revised: 6 September 2017 - Accepted: 6 September 2017 - Published: 11 October 2017

\begin{abstract}
Chromophoric dissolved organic matter (CDOM) plays a vital role in the biogeochemical cycle in aquatic ecosystems. The relationship between CDOM and dissolved organic carbon (DOC) has been investigated, and this significant relationship lays the foundation for the estimation of DOC using remotely sensed imagery data. The current study examined samples from freshwater lakes, saline lakes, rivers and streams, urban water bodies, and ice-covered lakes in China for tracking the variation of the relationships between DOC and CDOM. The regression model slopes for DOC vs. $a_{\mathrm{CDOM}}(275)$ ranged from extremely low 0.33 (highly saline lakes) to 1.03 (urban waters) and 3.01 (river waters). The low values were observed in saline lake waters and waters from semi-arid or arid regions, where strong photobleaching is expected due to less cloud cover, longer water residence time, and daylight hours. In contrast, high values were found in waters developed in wetlands or forest in Northeast China, where more organic matter was transported from catchment to waters. The study also demonstrated that closer relationships between CDOM and DOC were revealed when $a_{\mathrm{CDOM}}$ (275) were sorted by the ratio of $a_{\mathrm{CDOM}}(250) / a_{\mathrm{CDOM}}(365)$, which is a measure for the CDOM absorption with respect to its composition, and the determination of coefficient of the regression models ranged from 0.79 to 0.98 for different groups of waters. Our results indicate the relationships between CDOM and DOC are variable for different inland waters; thus, models for DOC estimation through linking with CDOM absorption need to be tailored according to water types.
\end{abstract}

\section{Introduction}

Inland waters play a disproportionate role in global carbon cycling with respect to carbon transportation, transformation, and carbon storage (Tranvik et al., 2009; Raymond et al., 2013; Verpoorter et al., 2014; Yang et al., 2015). However, the amount of dissolved organic carbon (DOC) stored in the inland waters is still unclear or the uncertainty is still needed to be evaluated (Tranvik et al., 2009). Determination of DOC concentration is straightforward through field sampling and laboratory analysis (Findlay and Sinsabaugh, 2003). However, there are millions of lakes in the world, and many of them are remote and inaccessible, making it impossible to evaluate DOC concentrations using routine approachs (Cardille et al., 2013; Brezonik et al., 2015; Pekel et al., 2016). Researchers have found that remote sensing might provide a promising tool for quantification of DOC in inland waters on a large scale through linking DOC with chromophoric dissolved organic matter (CDOM), particularly for inland waters situated in remote areas with little accessibility (Tranvik et al., 2009; Kutser et al., 2015; Brezonik et al., 2015).

As one of the optically active constituents in waters, CDOM can be estimated through remotely sensed signals (Yu et al., 2010; Kutser et al., 2015), and acts as a proxy in many regions for the amount of DOC in the water column. As shown in Fig. 1, CDOM and DOC in the aquatic ecosystems are mainly originated from natural external (allochthonous) and internal (autochthonous) sources, in addition to direct discharge from anthropogenic activities (Zhou et al., 2016). Generally, the autochthonous CDOM essentially originates from algae and macrophytes, and mainly consists of various compounds of low molecular weights 
(Findlay and Sinsabaugh, 2003; Zhang et al., 2010). The allochthonous CDOM is mainly derived from the surrounding terrestrial ecosystems, and it comprises a continuum of small organic molecules to highly polymeric humic substances. In terms of CDOM originating from anthropogenic sources, it contains fatty acids, amino acids, and sugar; thus, the composition of CDOM is more complex than that from natural systems (Zhou et al., 2016; Zhao et al., 2016a). Hydrological factors also affect the DOC and CDOM characteristics and particularly the discharge, catchment area, land use, and travel time are the important ones (Neff et al., 2006; Jaffé et al., 2008; Spencer et al., 2012).

CDOM is a light-absorbing constituent, which is partially responsible for the color in waters (Bricaud et al., 1981; Reche et al., 1999; Babin et al., 2003). The chemical structure and origin of CDOM can be characterized by its absorption coefficients $\left(a_{\mathrm{CDOM}}(\lambda)\right)$ and spectral slopes (De Haan and De Boer, 1987; Helms et al., 2008). Weishaar et al. (2003) has proven that the carbon specific absorption coefficient at $254 \mathrm{~nm}$, e.g., $\mathrm{SUVA}_{254}$ is a good tracer for the aromaticity of humic acid in CDOM, while the ratio of CDOM absorption at 250 to $365 \mathrm{~nm}$, i.e., $a_{\mathrm{CDOM}}(250) / a_{\mathrm{CDOM}}(365)$ herein $M$ value, has been successfully used to track the variation in DOM molecular weight (De Haan and De Boer, 1987). Biodegradation and photodegradation are the major processes to determine the transformation and composition of CDOM (Findlay and Sinsabaugh, 2003; Zhang et al., 2010), which ultimately affect the relationship between DOC and CDOM (Spencer et al., 2012; Yu et al., 2016). With prolonged sunlight radiation, some of the colored fraction of CDOM is lost by the photobleaching processes (Miller et al., 1995; Zhang et al., 2010), which can be measured by the light absorbance decreasing at some specific (diagnostic) wavelength, e.g., 250, $254,275,295,360$, and $440 \mathrm{~nm}$.

It should be noted that $a_{\mathrm{CDOM}}$ (440) is usually used by the remote sensing community due to this wavelength being overlapped with pigment absorption at $443 \mathrm{~nm}$; thus, reporting $a_{\mathrm{CDOM}}(440)$ has the potential to improve chlorophyll $a$ estimation accuracy (Lee et al., 2002). The relationship between CDOM and DOC varies since CDOM loses color, while the variation of DOC concentration is almost negligible. Saline or brackish lakes in the arid or semi-arid regions are generally exposed to longer sunlight radiation; thus, CDOM absorbance decreases, while DOC is accumulated due to the longer residence time (Curtis and Adams, 1995; Song et al., 2013; Wen et al., 2016). Compared to photodegradation of CDOM, the biodegradation processes by microbes are much more complicated, and extracellular enzymes are the key factors required to decompose the highmolecular-weight CDOM into low-molecular-weight substrates (Findlay and Sinsabaugh, 2003). With compositional change, the absorption feature of CDOM and its relation to DOC varies correspondingly, and the relationship between CDOM and DOC needs to be systematically exam- ined (Gonnelli et al., 2013). In addition, the SUVA 254 and $M$ value may be used to classify CDOM into different groups and enhance the relationship with DOC based on CDOM absorption grouping.

Some studies have investigated the spatial and seasonal variations in CDOM and DOC in ice-free season in lakes, rivers, and oceans (Vodacek et al., 1997; Neff et al., 2006; Stedmon et al., 2011; Brezonik et al., 2015), but less is known about saline lakes (Song et al., 2013; Wen et al., 2016). Even less is known about urban waters influenced by sewage effluent and waters with ice cover in winter (Belzile et al., 2002; Zhao et al., 2016b). A significant relationship between CDOM and DOC was observed in the Gulf of Mexico, and a stable regression model was established between DOC and $a_{\mathrm{CDOM}}$ (275) and $a_{\mathrm{CDOM}}$ (295) (Fichot and Benner, 2011). Similar results were also found in other estuaries along a salinity gradient, for example the Baltic Sea surface water (Kowalczuk et al., 2010) and the Chesapeake Bay (Le et al., 2013). However, Chen et al. (2004) found that the relationship between CDOM and DOC was not conservative due to estuarine mixing or photodegradation. Similar arguments were raised for the Congo River and waters across mainland USA (Spencer et al., 2009, 2012). In addition, seasonal variations were observed in some studies due to the mixing of various end-members of CDOM from different terrestrial ecosystems and internal sources (Zhang et al., 2010; Spencer et al., 2012; Yu et al., 2016; Zhou et al., 2016).

As demonstrated in Fig. 1, several factors influence the association between DOC and CDOM; thus, the relationship between DOC and CDOM may vary with respect to their origins, photo- or bio-degradations (Williamson and Rose, 2010), and hydrological features, which is worth systematic examination. In this study, the characteristics of DOC and $\mathrm{CDOM}$ in different inland waters across China were examined to determine the spatial features associated with landscape variations, hydrologic conditions and saline gradients. The objectives of this study are to (1) examine the relationship between CDOM and DOC concentrations across a wide range of waters with various physical, chemical, and biological conditions, and (2) develop a model for the relationship between DOC and CDOM based on the sorted CDOM absorption feature, e.g., the $M$ values, and aiming to improve the regression modeling accuracy.

\section{Materials and methods}

The dataset is composed of five subsets of samples collected from various types of waters across China (Table 1; Fig. 2), which encompassed a wide range of DOC and CDOM concentrations. The first dataset $(n=288$; from early spring 2009 to late October 2014) includes samples collected in freshwater lakes and reservoirs during the growing season with various landscape types. The second dataset $(n=345$; from early spring 2010 to mid-September 2014) 


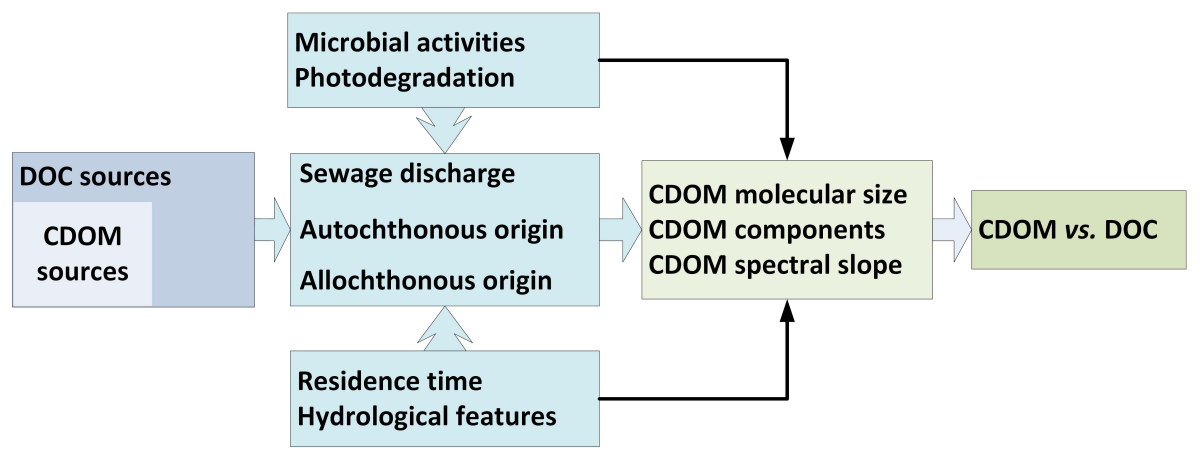

Figure 1. The potential regulating factors that influence the relationship between CDOM and DOC. Note, CDOM sources are a subset of DOC sources, and hydrological features include flow discharge, drainage area, catchment landscape, river level, and inflow or outflow regions.

includes samples collected in brackish to saline water bodies. The third dataset ( $n=322$; from early May 2012 to late July 2015) includes samples collected in rivers and streams across different basins in China. In addition, 69 samples were collected from three sections along the Songhua River, the Yalu, and the Hunjiang River during the ice-free period in 2015 to examine the impact of river flow on the relationship between DOC and CDOM (see Fig. S1 for locations). The fourth dataset $(n=328$; from 2011 to 2014 in the ice frozen season) includes samples collected in Northeast China in winter from both lake ice and underlying waters. The fifth dataset $(n=221$; from early May 2013 to mid-October 2014) collects samples in urban water bodies, including lakes, ponds, rivers, and streams, which were severely polluted by sewage effluents. City maps and Landsat imagery data acquired in 2014 or 2015 were used to delineate urban boundaries with ArcGIS 10.0 (ESRI Inc., Redlands, California, USA), and water bodies in these investigated cities constrained by urban boundaries were considered as urban water bodies. The sampling dates, water body names, and locations of other types of water bodies are provided in the Supplement (Tables S1-S4).

\subsection{Water quality determination}

Water samples were collected approximately $0.5 \mathrm{~m}$ below the water surface at each station, generally locating in the middle of water bodies. Water samples were collected in two $1 \mathrm{~L}$ amber HDPE bottles and kept in coolers with ice packs in the field, and kept in a refrigerator at $4^{\circ} \mathrm{C}$ after shipping back to the laboratory. All samples were preprocessed (e.g., filtration, $\mathrm{pH}$, and electrical conductivity, EC, determination) within 2 days in the laboratory. Water salinity was measured using a DDS-307 EC meter $\left(\mu \mathrm{S} \mathrm{cm}^{-1}\right)$ at room temperature $\left(20 \pm 2^{\circ} \mathrm{C}\right)$ in the laboratory and converted to in situ salinity, expressed in practical salinity units (PSU). Water samples were filtered using Whatman cellulose acetone filters with a pore size of $0.45 \mu \mathrm{m}$. Chlorophyll $a$ (Chl $a$ ) was extracted and the concentration was measured using a Shimadzu UV-
2600PC spectrophotometer, the details can be found in Jeffrey and Humphrey (1975). Total suspended matter (TSM) was determined gravimetrically using precombusted Whatman GF/F filters with a $0.7 \mu \mathrm{m}$ pore size, details can be found in Song et al. (2013). DOC concentrations were measured by high temperature combustion (HTC) with water samples filtered through $0.45 \mu \mathrm{m}$ Whatman cellulose acetone filters (Zhao et al., 2016a). The standards for dissolved total carbon (DTC) were prepared from reagent grade potassium hydrogen phthalate in ultra-pure water, while dissolved inorganic carbon (DIC) concentrations were determined using a mixture of anhydrous sodium carbonate and sodium hydrogen carbonate. DOC was calculated by subtracting DIC from DTC, both of which were measured using a total organic carbon analyzer (TOC-VCPN, Shimadzu, Japan). Total nitrogen $(\mathrm{TN})$ was measured based on the absorption levels at $146 \mathrm{~nm}$ of water samples decomposed with alkaline potassium peroxydisulfate. Total phosphorus (TP) was determined using the molybdenum blue method after the samples were digested with potassium peroxydisulfate (APHA, 1998). $\mathrm{pH}$ was measured using a PHS-3C pH meter at room temperature $\left(20 \pm 2^{\circ} \mathrm{C}\right)$.

\subsection{CDOM absorption measurement}

All water samples were filtered at low pressure in two steps: (1) filtered at low pressure through a precombusted Whatman GF/F filter $(0.7 \mu \mathrm{m})$ and (2) further filtered through prerinsed $25 \mathrm{~mm}$ Millipore membrane cellulose filter $(0.22 \mu \mathrm{m})$. Absorption spectra were obtained between 200 and $800 \mathrm{~nm}$ at $1 \mathrm{~nm}$ increment using a Shimadzu UV-2600PC UV-Vis dual beam spectrophotometer (Shimadzu Inc., Japan) through a $1 \mathrm{~cm}$ quartz cuvette (or $5 \mathrm{~cm}$ cuvette for ice melted water samples). Milli-Q water was used as reference for CDOM absorption measurements. The Napierian absorption coefficient $\left(a_{\mathrm{CDOM}}\right)$ was calculated from the measured optical density (OD) of samples using Eq. (1):

$a_{\mathrm{CDOM}}(\lambda)=2.303\left(\mathrm{OD}_{S(\lambda)}-\mathrm{OD}_{(\mathrm{null})}\right) / \beta$, 


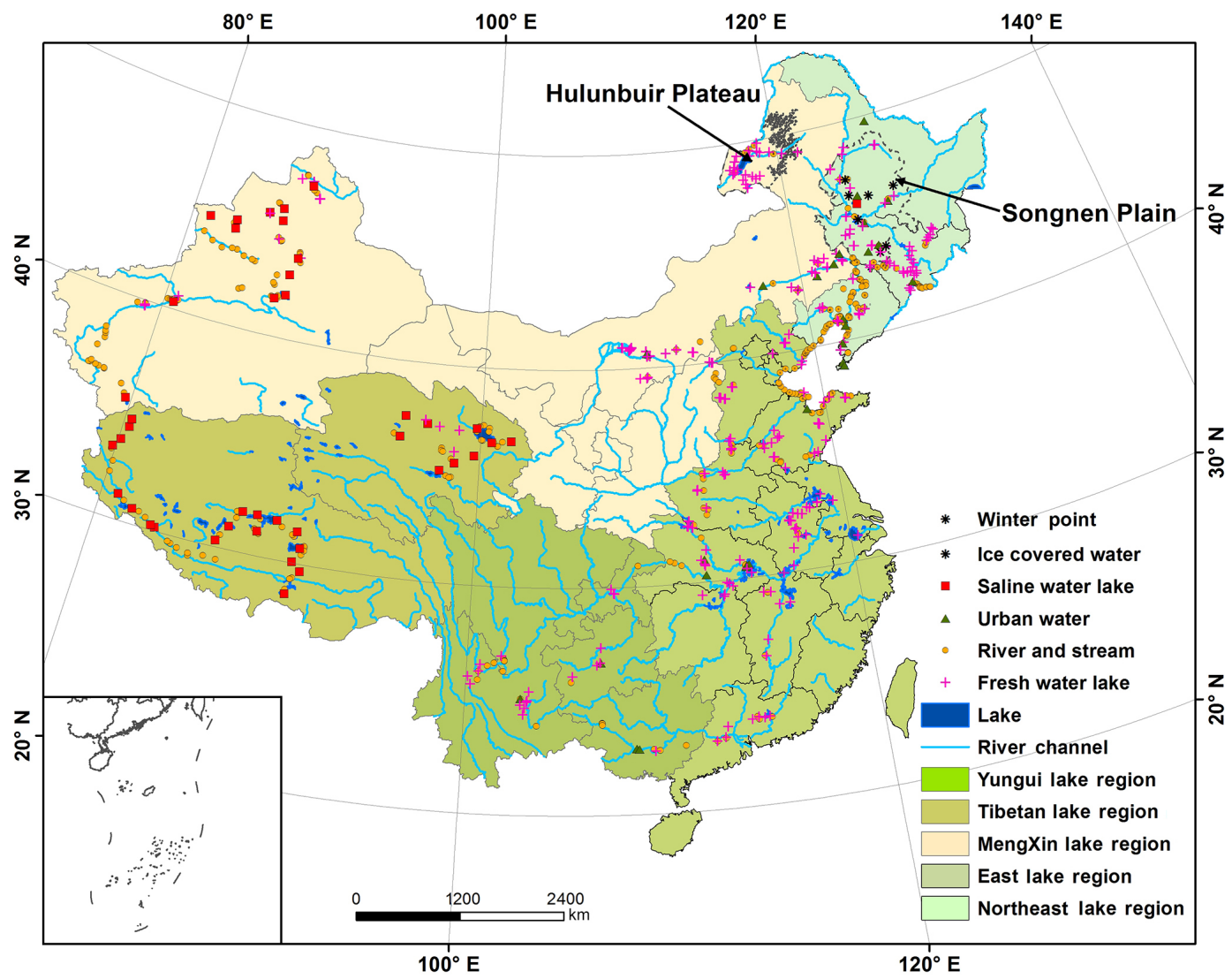

Figure 2. Water types and sample distributions across mainland China. The dashed line shows the boundary of some typical geographic units (i.e., Songnen Plain and Hulunbuir Plateau).

Table 1. Water quality in different types of waters. DOC, dissolved organic carbon; EC, electrical conductivity; TP, total phosphorus; TN, total nitrogen; TSM, total suspended matter; and Chl $a$, chlorophyll $a$ concentration.

\begin{tabular}{llrrrrrrr}
\hline \multirow{2}{*}{ FW } & & $\begin{array}{r}\mathrm{DOC} \\
\left(\mathrm{mgL}^{-1}\right)\end{array}$ & $\begin{array}{r}\mathrm{EC} \\
\left(\mu \mathrm{cm}^{-1}\right)\end{array}$ & $\mathrm{pH}$ & $\begin{array}{r}\mathrm{TP} \\
\left(\mathrm{mgL}^{-1}\right)\end{array}$ & $\begin{array}{r}\mathrm{TN} \\
\left(\mathrm{mgL}^{-1}\right)\end{array}$ & $\begin{array}{r}\text { TSM } \\
\left(\mathrm{mgL}^{-1}\right)\end{array}$ & $\begin{array}{r}\text { Chl } a \\
\left(\mu \mathrm{gL}^{-1}\right)\end{array}$ \\
& Mean & 10.2 & 434.0 & 8.2 & 0.5 & 1.6 & 67.8 & 78.5 \\
SW & Range & $1.9-90.2$ & $72.7-1181.5$ & $6.9-9.3$ & $0.01-10.4$ & $0.001-9.5$ & $0-1615$ & $1.4-338.5$ \\
& Mean & 27.3 & 4109.4 & 8.6 & 0.4 & 1.4 & 115.7 & 9.0 \\
\multirow{2}{*}{ RW } & Range & $2.3-300.6$ & $1067-41000$ & $7.1-11.4$ & $0.01-6.3$ & $0.6-11.0$ & $1.4-2188$ & $0-113.7$ \\
& Mean & 8.3 & 10489.1 & $7.8-9.5$ & - & - & - & - \\
\multirow{2}{*}{$\mathrm{UW}$} & Range & $0.9-90.2$ & $3.7-1000$ & 8.6 & - & - & - & - \\
\multirow{2}{*}{ WW } & Mean & 19.44 & 525.4 & 8.0 & 3.4 & 3.5 & 50.5 & 38.9 \\
& Range & $3.5-123.3$ & $28.6-1525$ & $6.4-9.2$ & $0.03-32.4$ & $0.04-41.9$ & $1-688$ & $1.0-521.1$ \\
IMW & Mean & 67.0 & 1387.6 & 8.1 & 0.7 & 4.3 & 181.5 & 7.3 \\
& Range & $7.3-720$ & $139-15080$ & $7.0-9.7$ & $0.1-4.8$ & $0.5-48$ & $9.0-2174$ & $1.0-159.4$ \\
& Mean & 6.7 & 242.8 & 8.3 & 0.19 & 1.1 & 17.4 & 1.1 \\
& Range & $0.3-76.5$ & $1.5-4350$ & $6.7-10$ & $0.02-2.9$ & $0.3-8.6$ & $0.3-254.6$ & $0.28-5.8$ \\
\hline
\end{tabular}

Note: FW, fresh water lake; SW, saline water lake; RW, river or stream water; UW, urban water; WW, ice-covered winter water from Northeast China; and IMW, ice melt water from Northeast China.

where $\beta$ is the cuvette path length ( 0.01 or $0.05 \mathrm{~m})$ and 2.303 is the conversion factor of base 10 to base $e$ logarithms. To remove the scattering effect from the limited number of fine particles that remained in the filtered solutions, a necessary correction was implemented by assuming the average OD over $740-750 \mathrm{~nm}$ to be zero (Babin et al., 2003). SUVA 254 and $M$ values were calculated to characterize CDOM with respect to their compositional features. In addition, $a_{\mathrm{CDOM}}$ 
was divided into different groups according to their $M$ values by a hierarchical cluster approach, which was performed in the SPSS software package with the pairwise distance between samples measured by squared Euclidean distance and the clusters were linked together by Ward's linkage method (Ward Jr, 1963). The method has been applied to classify the waters into different types according to the remote sensing spectra (Vantrepotte et al., 2012; Shi et al., 2013).

\section{Results}

\subsection{Water quality characteristics}

Chl $a$ concentrations $\left(46.44 \pm 59.71 \mu \mathrm{gL}^{-1}\right)$ ranged from 0.28 to $521.12 \mu \mathrm{g} \mathrm{L}-1$. TN and TP concentrations were very high in fresh lakes, saline lakes, and particularly in urban water bodies (Table 1). It is worth noting that $\mathrm{Chl} a$ concentration was still high $7.3 \pm 19.7 \mu \mathrm{g} \mathrm{L}-1$ even in ice-covered lakes in winter from Northeast China. EC and $\mathrm{pH}$ were high in the semi-arid and arid regions, they were $1067-41000 \mu \mathrm{sm}^{-1}$ and 7.1-11.4, respectively. Overall, waters were highly turbid with high TSM concentrations $\left(119.6 \pm 131.4 \mathrm{mg} \mathrm{L}^{-1}\right)$, and apparent variations were observed for different types of waters (Table 1). Hydrographic conditions exerted a strong impact on water turbidity and TSM concentration; thus, these two parameters of river and stream samples were excluded in this study (Table 1).

\subsection{DOC concentrations in different types of waters}

DOC concentrations changed remarkably in the investigated waters (Table 1). The concentrations of DOC were low in rivers, and the lowest DOC concentrations were measured in ice-melting waters. It should be noted that large variations were observed in water samples from rivers and streams (Table 2). Among the five types of waters, relatively higher DOC concentrations, ranging from 2.3 to $300.6 \mathrm{mg} \mathrm{L}^{-1}$, were found in many saline lakes, in the Songnen Plain, the Hulunbuir Plateau and some areas in the Tibetan Plateau (see Fig. 2 for locations). However, some of the saline lakes supplied by snow melt water or ground water exhibited relatively lower DOC concentrations even with high salinity. Compared with samples collected in growing seasons, higher DOC concentrations (7.3-720 $\mathrm{mg} \mathrm{L}^{-1}$ ) were observed in icecovered water bodies.

\subsection{DOC vs. CDOM for various types of waters}

\subsubsection{Freshwater lakes and reservoirs}

The relationship between DOC and CDOM has been investigated based on CDOM absorption at different wavelengths (Fichot and Benner, 2011; Spencer et al., 2012; Song et al., 2013; Brezonik et al., 2015). As suggested by Fichot and Benner (2011), CDOM absorptions at $275 \mathrm{~nm}\left(a_{\mathrm{CDOM}}\right.$
(275)) and $295 \mathrm{~nm}\left(a_{\mathrm{CDOM}}(295)\right)$ have stable performances for DOC estimates for coastal waters. In the current study, a strong relationship $\left(R^{2}=0.85\right)$ between DOC and $a_{\mathrm{CDOM}}$ (275) was found in fresh water lakes and reservoirs (Fig. 3a). However, the inclusion of $a_{\mathrm{CDOM}}$ (295) explains a very limited variance; thus, it is not considered in the regression models. Regression analyses of water samples collected from different regions indicated that the slopes varied from 1.30 to 3.01 (Table 3). Water samples collected from east China and south China had lower regression slope values (Table 3), and lakes and reservoirs were generally mesotrophic or eutrophic (Huang et al., 2014; Yang et al., 2012, and references therein).

\subsubsection{Saline lakes}

A strong relationship between DOC and $a_{\mathrm{CDOM}}(275)\left(R^{2}=\right.$ 0.85 ) was demonstrated for saline lakes (Fig. 3b) with a much lower regression slope value (slope $=1.28$ ). Further, the regression slopes exhibited large variations in different regions (Table 3), ranging from 0.86 in Tibetan waters to 2.83 in the Songnen Plain waters (see Fig. 2 for location). As the extreme case, the slope value was only 0.33 as demonstrated in the embedded diagram in Fig. 3b. Saline lakes in semiarid or arid regions generally exhibit higher regression slope values, for example, the west Songnen Plain (2.83), the Hulunbir Plateau and the East Inner Mongolia Plateau (1.79). Whereas, waters in the west Inner Mongolia Plateau (1.13) and the Tibetan Plateau (0.86) exhibited low slope values (Table 3), and the extremely low value was measured in Qinhai Lake in the Tibetan Plateau.

\subsubsection{Streams and rivers}

Although some of the samples scattered from the regression line (Fig. 3c), a close relationship between DOC and $a_{\mathrm{CDOM}}(275)$ was found for samples collected in rivers and streams. Compared with the other water types (Fig. 3), rivers and streams exhibited the highest regression slope value (slope $=3.01$ ). Further regression analysis with water sample sub-datasets collected in different regions indicated that slope values presented large variability, ranging from 1.07 to 8.49. The lower regression slope values were recorded in water samples collected in rivers and stream in semi-arid and arid regions, such as the Tibetan Plateau, Mongolia Plateau, and Tarim Basin, while the higher values were found in samples collected in streams originated from wetland and forest in Northeast China (Table 3).

To investigate the dynamics of CDOM absorption and DOC concentrations, three sections were investigated in three major rivers in Northeast China (see Fig. S1 for location). River flow exerted an obvious effect on DOC and CDOM (Fig. 4) and flood impulse brought large amounts of DOC and CDOM into river channels. The relationships between DOC and $a_{\mathrm{CDOM}}(275)$ in sections along three rivers 
Table 2. Descriptive statistics of dissolved organic carbon (DOC) and $a_{\mathrm{CDOM}}$ (440) in various types of waters. Min, minimum; Max, maximum; and SD, standard deviation.

\begin{tabular}{|c|c|c|c|c|c|c|c|c|c|}
\hline \multirow[t]{2}{*}{ Type } & \multirow[t]{2}{*}{ Region } & \multicolumn{3}{|c|}{$\mathrm{DOC}\left(\mathrm{mg} \mathrm{L}^{-1}\right)$} & \multicolumn{5}{|c|}{$a_{\mathrm{CDOM}}(440)\left(\mathrm{m}^{-1}\right)$} \\
\hline & & Min & $\operatorname{Max}$ & Mean & SD & Min & Max & Mean & SD \\
\hline \multirow[t]{4}{*}{ River } & Liaohe & 3.6 & 48.2 & 14.3 & 9.49 & 0.46 & 3.68 & 0.92 & 0.58 \\
\hline & Qinghai & 1.2 & 8.5 & 4.4 & 1.96 & 0.13 & 2.11 & 0.54 & 0.63 \\
\hline & Inner Mongolia & 16.9 & 90.2 & 40.4 & 24.84 & 0.32 & 7.46 & 1.03 & 2.11 \\
\hline & Songhua & 0.9 & 21.1 & 8.1 & 4.96 & 0.32 & 18.93 & 3.2 & 4.19 \\
\hline \multirow[t]{4}{*}{ Saline } & Qinghai & 1.7 & 130.9 & 67.9 & 56.7 & 0.13 & 0.86 & 0.36 & 0.23 \\
\hline & Hulunbir & 8.4 & 300.6 & 68.5 & 69.2 & 0.82 & 26.21 & 4.41 & 4.45 \\
\hline & Xilinguole & 3.74 & 45.4 & 14.2 & 8.8 & 0.36 & 4.7 & 1.34 & 0.88 \\
\hline & Songnen & 3.6 & 32.6 & 16.4 & 7.4 & 0.46 & 33.80 & 2.4 & 3.78 \\
\hline
\end{tabular}

Table 3. Fitting equations for DOC vs. $a_{\mathrm{CDOM}}(275)$ in different types of waters (except ice-covered lake underlying water and ice-melting waters).

\begin{tabular}{lllrr}
\hline Water types & Region or basin & Equations & $R^{2}$ & $N$ \\
\hline \multirow{2}{*}{ Freshwater lakes } & northeast lake region & $y=3.13 x-3.438$ & 0.87 & 102 \\
& Mengxin lake region & $y=2.16 x-1.279$ & 0.90 & 63 \\
& east lake region & $y=1.98 x+7.813$ & 0.66 & 69 \\
& Yungui lake region & $y=1.295 x-44.56$ & 0.71 & 54 \\
\hline \multirow{2}{*}{ Saline lakes } & Songnen Plain & $y=2.383 x+1.101$ & 0.92 & 159 \\
& east Mongolia & $y=1.791 x+8.560$ & 0.67 & 57 \\
& west Mongolia & $y=1.133 x+3.900$ & 0.81 & 46 \\
& Tibetan lake region & $y=0.864 x+2.255$ & 0.84 & 83 \\
\hline \multirow{2}{*}{ Rivers or streams } & branch of the Nenjiang River & $y=7.655 x-42.64$ & 0.81 & 33 \\
& Songhua River stem & $y=3.759 x-6.618$ & 0.71 & 29 \\
& branch of Songhua River & $y=8.496 x-12.14$ & 0.98 & 33 \\
& Liao River autumn 2012 & $y=1.099 x+3.900$ & 0.80 & 38 \\
& Liao River autumn 2013 & $y=1.073 x-4.157$ & 0.88 & 28 \\
& rivers from North China & $y=3.154 x-1.207$ & 0.87 & 48 \\
& rivers from East China & $y=3.037 x-2.585$ & 0.88 & 47 \\
& rivers from Tibetan Plateau & $y=2.345 x+2.375$ & 0.87 & 41 \\
\hline Urban waters & waters from Changchun & $y=2.471 x-2.231$ & 0.54 & 48 \\
& waters from Harbin & $y=1.413 x-4.521$ & 0.67 & 31 \\
& waters from Beijing & $y=0.874 x+11.12$ & 0.63 & 27 \\
& waters from Tianjin & $y=0.994 x+7.368$ & 0.57 & 23 \\
\hline
\end{tabular}

in Northeast China were demonstrated in Fig. 5. The sampling point in the Yalu River is near the river head source; thus, a strong relationship $\left(R^{2}=0.92\right)$ was exhibited with a large slope (Fig. 5a). The relationship between DOC and $a_{\mathrm{CDOM}}(275)$ in the Songhua River at the Harbin city section was much scattered $\left(R^{2}=0.64\right.$; Fig. $\left.5 \mathrm{c}\right)$. With respect to Fig. $5 b$, it is an in-between case $\left(R^{2}=0.82\right)$. The sampling point was affected by effluent from Baishan; thus, the coefficient of determination $\left(R^{2}=0.822\right)$ and the regression slope (3.72) were lower than that from the Yalu River at Changbai, while higher than that from the Songhua River at Harbin.

\subsubsection{Urban waters}

As shown in Fig. 3d, a relatively close relationship between DOC and $a_{\mathrm{CDOM}}$ (275) was revealed in urban waters $\left(R^{2}=\right.$ $0.71, p<0.001)$. Similarly, regression slope values for urban waters also changed remarkably, ranging from 0.87 to 2.45 (Table 3). High nutrients in urban waters (Table 1) usually result in algal bloom in most urban water bodies (Chl $a$ range: 1.0-521.1 $\mu \mathrm{g} \mathrm{L}^{-1}$; average: $38.9 \mu \mathrm{gL}^{-1}$ ), which might contribute to the high DOC concentrations in urban waters (Table 1). Thereby, the contribution from algal decomposition and cell lysis to DOC and CDOM should not be neglected 

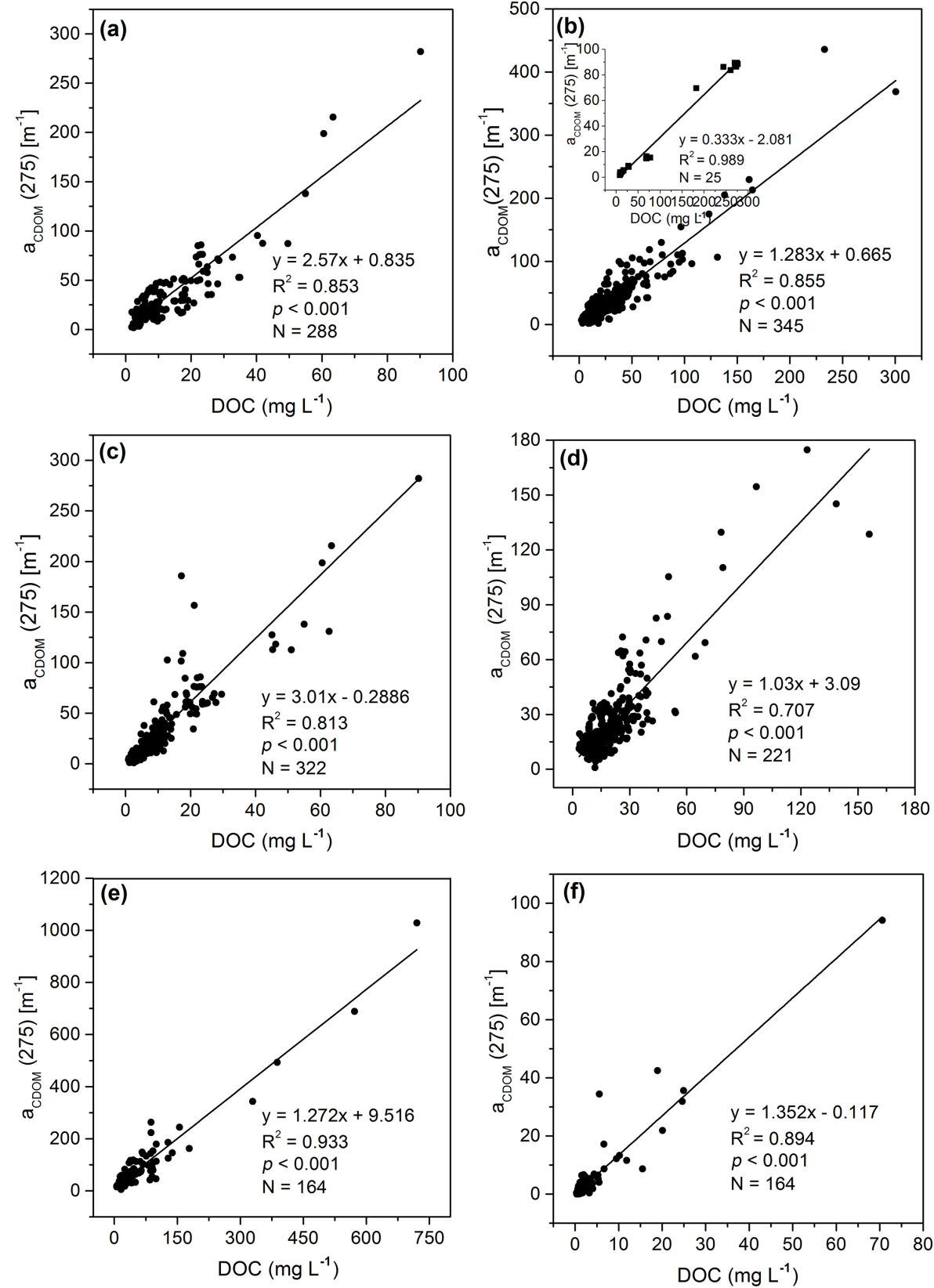

Figure 3. Relationships between DOC and $a_{\mathrm{CDOM}}(275)$ in different types of inland waters: (a) fresh water lakes, (b) saline water lakes, (c) river and stream waters, (d) urban waters, (e) ice-covered lake underlying waters, and (f) ice-melting lake waters. The regression metrics without these high DOC concentrations in (b-f) are listed in Table S6.

for urban waters (Zhang et al., 2010; Zhao et al., 2016b; Zhou et al., 2016).

\subsubsection{Ice-covered lakes and reservoirs}

The closest relationship $\left(R^{2}=0.93\right)$ between DOC and $a_{\mathrm{CDOM}}(275)$ was recorded in waters beneath ice-covered lakes and reservoirs in Northeast China (Fig. 3e). Comparatively, a weak relationship between DOC and $a_{\mathrm{CDOM}}$ (275) was demonstrated in ice-melting waters (Fig. 3f). Ap- parently, CDOM from ice-melting waters mainly originated from maternal water during the ice formation and also from algal biological processes (Stedmon et al., 2011; Arrigo et al., 2010). Interestingly, the regression slopes for ice samples (1.35) and underlying water sample (1.27) are very close. In addition, there was a significant relationship between DOC in ice and underlying waters $\left(R^{2}=0.86\right)$, indicating the dominant components of CDOM and DOC in the ice are from maternal underlying waters. 

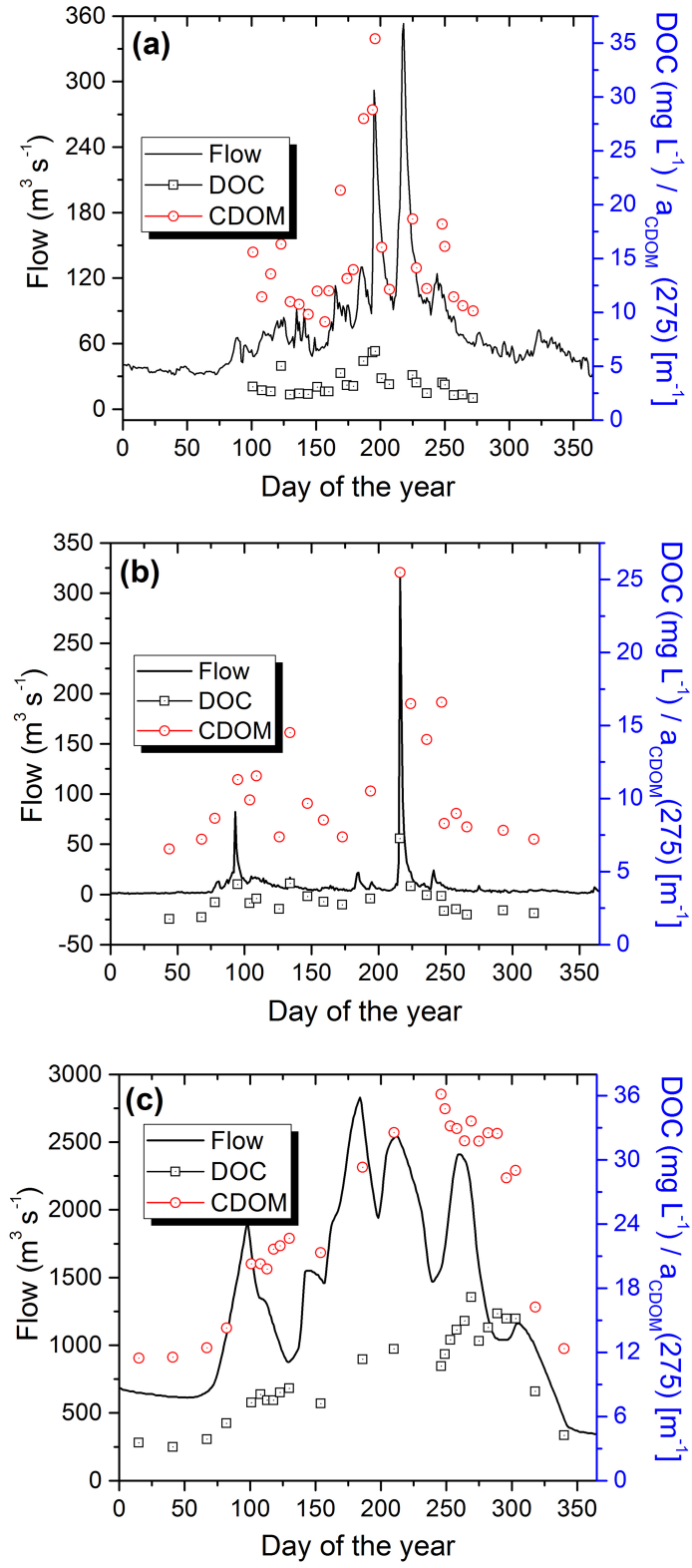

Figure 4. Concurrent flow dynamics for three rivers in Northeast China and the corresponding DOC and CDOM variations in 2015; (a) the Yalu River near Changbai county, (b) the Hunjiang River with DOC and CDOM sampled at Baishan, while the river flow gauge station is near Tonghua, and (c) the Songhua River at Harbin.

\subsubsection{DOC vs. $a_{\text {CDOM }}(440)$}

CDOM absorption at $440 \mathrm{~nm}$, i.e., $a_{\mathrm{CDOM}}$ (440), is usually used as a surrogate to represent its concentration (Bricaud et al., 1981; Babin et al., 2003), and widely used in the remote sensing community to quantify CDOM in waters (Lee et al., 2002; Binding et al., 2008; Zhu et al., 2014). Significant relationships between DOC and $a_{\mathrm{CDOM}}(440)$ were found in different types of waters (Fig. 5). By comparing
Fig. 3 with Fig. 6, it can be found that the overall relationships between DOC and CDOM at $440 \mathrm{~nm}$ resembled that at $275 \mathrm{~nm}$ for different types of waters, but with relatively loose relationship as indicated by the coefficients of determination (see Table S5). Further, it can be noted that some of the samples in Figs. 3b-f and 6b-f may leverage the regression model performances. Thus, regression models without these samples appearing to leverage the relationships were evaluated and provided in Table S6. Comparing Tables S5 and S6, the regression model performances were degraded, but still acceptable.

\subsection{CDOM molecular weight and aromaticity vs. DOC}

\subsubsection{CDOM vs. SUVA 254 and $M$ value $\left(a_{\text {CDOM }}(250) / a_{\text {CDOM }}(365)\right)$}

The large slope variations in regressions between DOC and $a_{\mathrm{CDOM}}(275)$ in different types of waters are probably due to the aromaticity and colored fractions in the DOC component (Spencer et al., 2009, 2012; Lee et al., 2015). As shown in Fig. 7a, it can be seen that SUVA $_{254}$ had high values in fresh water lakes, and waters from rivers or streams as well. Saline water and ice-covered waters in Northeast China showed intermediate $\mathrm{SUVA}_{254}$ values, while urban water and ice-melting water exhibited lower values. The $M$ value, i.e., $a_{\mathrm{CDOM}}(250) / a_{\mathrm{CDOM}}(365)$ is another indicator to demonstrate the variation of molecular weight of CDOM components (De Haan, 1993). Compared to saline water, fresh lake water ( $t$ test: $F=631, p<0.01$ ), river and stream water ( $t$ test: $F=565, p<0.001)$, and urban water $(t$ test: $F=$ 393, $p<0.001$ ) exhibited low $M$ values (Fig. 7b), which indicated that large molecular weight molecules dominate in these three types of waters. Saline water, ice-covered water in Northeast China, and ice-melting water showed higher $M$ values. Since $\mathrm{SUVA}_{254}$ is a proxy based on the ratio to DOC, it is inappropriate to establish the relationship between CDOM and DOC based on the $\mathrm{SUVA}_{254}$ classification. Thereby, only $M$ values, which reveal molecular weight and aromaticity, might help to estimate DOC through CDOM absorption based on $M$ values for various types of waters.

\subsubsection{Regression based on $M$ values}

Regression models between DOC and $a_{\mathrm{CDOM}}$ (275) were established based on $M$ value grouping. Four groups were created with the hierarchical cluster approach, and each group occupied about $44.74 \%(M<9.0), 34.24 \%(9.0<M<$ $16.0), 18.22 \%(16.0<M<25.0)$, and $2.80 \%(25.0<M<$ 68.0) of the total samples from group 1 to 4 , respectively. Although only $M$ values were used in the cluster, which meant that the feature space in classification only had one dimension and the groups were mainly divided according to the distribution of $M$ values, the hierarchical cluster approach generated rational results. As shown in Fig. 8, a close rela- 

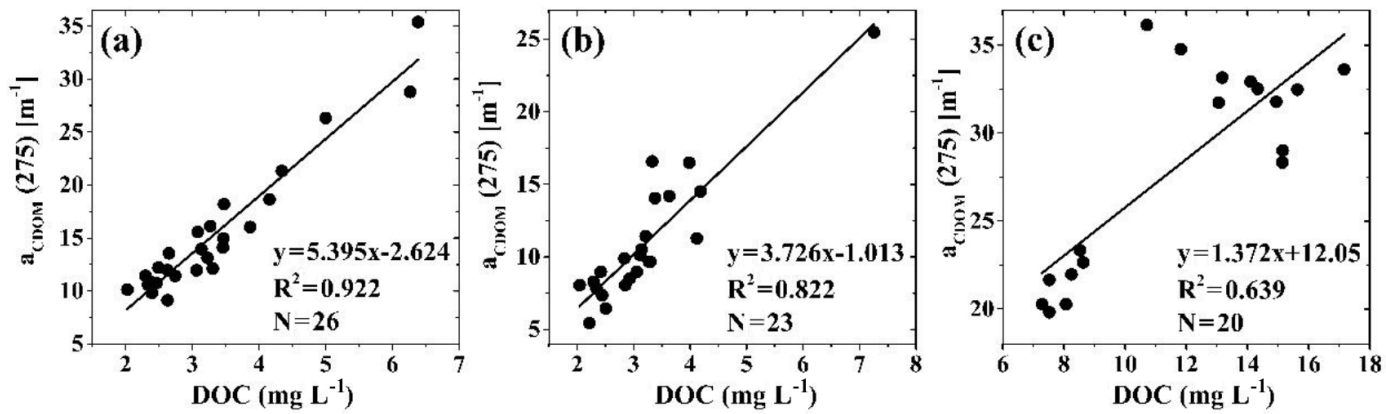

Figure 5. The relationships between $a_{\mathrm{CDOM}}(275)$ and DOC at sections across (a) the Yalu River, (b) the Hunjiang River, and (c) the Songhua River. The samples were collected at each station at about 1 week or around 10 days apart in the ice-free season in 2015.

tionship $\left(R^{2}=0.90\right)$ between DOC and $a_{\mathrm{CDOM}}(275)$ was revealed in datasets where $M<9.0$ (group 1). Likewise, a close relationship regression model appeared in datasets with intermediate $M$ values (group 2 in Fig. 8), revealing high determination coefficients $\left(R^{2}=0.91\right)$. A relatively weak relationship $\left(R^{2}=0.79\right)$ between DOC and $a_{\mathrm{CDOM}}(275)$ appeared with $M$ values ranging from 16.0 to 25.0 (group 3). A very close relationship $\left(R^{2}=0.98\right)$ was found with extremely high $M$ values (group 4 in Fig. 8).

As noted in Fig. 8, close regression slopes indicate that a comprehensive regression model with intermediate $M$ values less than 16 may be achieved. As expected, a promising regression model (diagram not shown) between DOC and $a_{\text {CDOM }}(275)$ was achieved $\left(y=1.269 x+6.42 ; R^{2}=0.909\right.$, $N=1171, p<0.001)$ with a pooled dataset in group 1 and group 2 shown in Fig. 8. Inspired by this idea, the relationship between $a_{\mathrm{CDOM}}$ (275) and DOC was also examined with pooled data. As shown in Fig. 9a, a significant relationship between DOC and $a_{\mathrm{CDOM}}$ (275) was obtained with the pooled dataset $(N=1504)$ collected from different types of inland waters. However, it should be noted that the extremely high DOC samples may advantageously contribute to the better performance of the regression model. Thus, a regression model excluding these eight samples $\left(\right.$ DOC $>300 \mathrm{mg} \mathrm{L}^{-1}$ ) was acceptable (Fig. 9b; $R^{2}=0.51, p<0.001$ ), but greatly degraded. In addition, a regression model with a power function was established in decimal logarithm log-log scale (Fig. 9c; $R^{2}=0.77, p<0.001$ ).

\section{Discussion}

\subsection{Variation of water quality parameters}

Different water types were sampled across China with different climatic, hydrologic, and land use conditions in various catchments combined with different anthropogenic intensity; thus, the biological and geochemical properties in the water bodies are quite diverse with a large range of values for each parameter (Table 1). Extremely turbid waters are observed for fresh waters, saline waters, and underlying waters covered by ice, which were generally collected in very shallow water bodies in different parts of China. As expected, large variations in Chl $a$ are observed for both fresh waters and urban waters, and particularly the samples collected in urban waters show a large range $\left(1.0-521.1 \mu \mathrm{gL}^{-1}\right)$. Our investigation also indicates that algal growth is still very active in these ice-covered water bodies in Northeast China, which might result from high TN $\left(4.3 \pm 5.4 \mathrm{mgL}^{-1}\right)$ and TP $\left(0.7 \pm 0.6 \mathrm{mg} \mathrm{L}^{-1}\right)$ concentrations in these waters bodies. It also should be noted that DOC, EC, and $\mathrm{pH}$ were high in semi-arid or arid climatic regions, which is consistent with previous findings (Curtis and Adams, 1995; Song et al., 2013; Wen et al., 2016).

\subsection{DOC variation with different types of waters}

This investigation indicates that lower DOC concentrations were encountered with samples collected in rivers from the Tibetan Plateau (Table 2), where the average soil organic matter is lower thus terrestrial DOC input from the catchment is less (Tian et al., 2008). However, high DOC concentrations were found in rivers or streams surrounded by forest or wetlands in Northeast China, the similar findings were also reported by Ågren et al. (2007, 2010). Further, lower DOC concentrations are also measured with ice samples, which is consistent with previous findings (Bezilie et al., 2002; Shao et al., 2016). But relatively high DOC concentrations were observed for underlying waters covered by ice in Northeast China due to the condensed effect caused by the DOC discharged from ice formation (Bezilie et al., 2002; Shao et al., 2016; Zhao et al., 2016a). This condensed effect was particularly marked in these shallow water bodies where ice forming remarkably condensed the DOC in the underlying waters (Zhao et al., 2016a). It also should be noted that DOC concentration has a strong connection with hydrological condition and catchment landscape features (Neff et al., 2006; Ågren et al., 2007; Lee et al., 2015). It should be noted that large DOC variations were observed in saline lakes in different regions (Table 2). Much higher DOC concentrations were found in saline lakes in Qinghai and Hulunbir, while rela- 

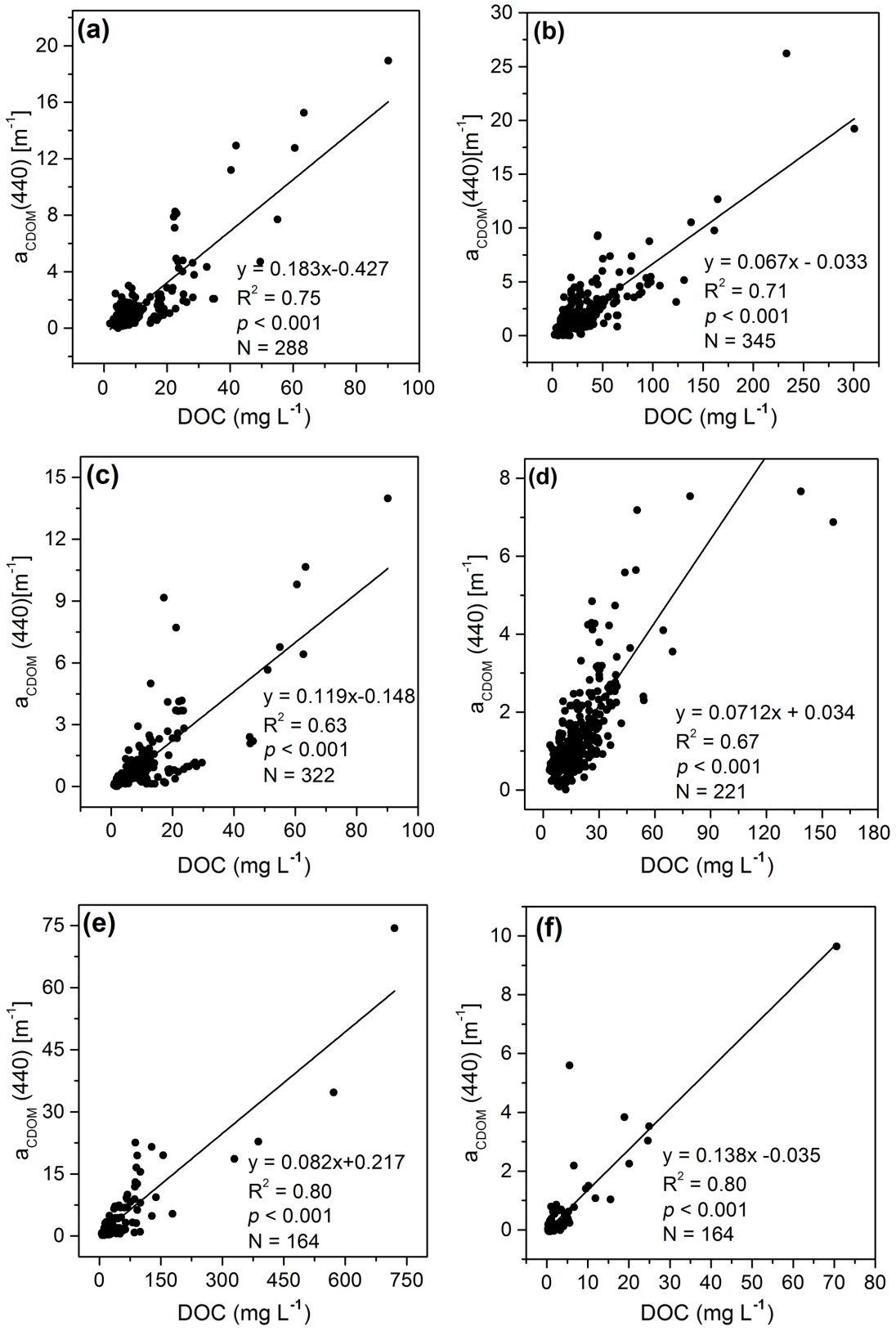

Figure 6. Relationships between DOC and $a_{\mathrm{CDOM}}(440)$ in different types of inland waters: (a) fresh water lakes, (b) saline water lakes, (c) river and stream waters, (d) urban waters, (e) ice-covered lake underlying waters, and (f) ice-melting waters. The regression metrics without these high DOC concentrations in (b-f) are listed in Table S6.

tively low concentrations were observed in the Xilinguole Plateau and the Songnen Plain, which is consistent with previous investigations conducted in the semi-arid or arid regions (Curtis and Adams, 1995; Song et al., 2013; Wen et al., 2016).

\subsection{Variation of the relationships between CDOM and DOC}

As demonstrated in Fig. 3, an obvious variation is revealed for the regression slope values between DOC and $a_{\mathrm{CDOM}}$ (275). Most of the fresh water bodies are located in east China, where agricultural pollution and anthropogenic discharge have resulted in serious eutrophication (Tong et al., 2017). Phytoplankton degradation may contribute to a relatively large portion of CDOM and DOC in these water bod- 

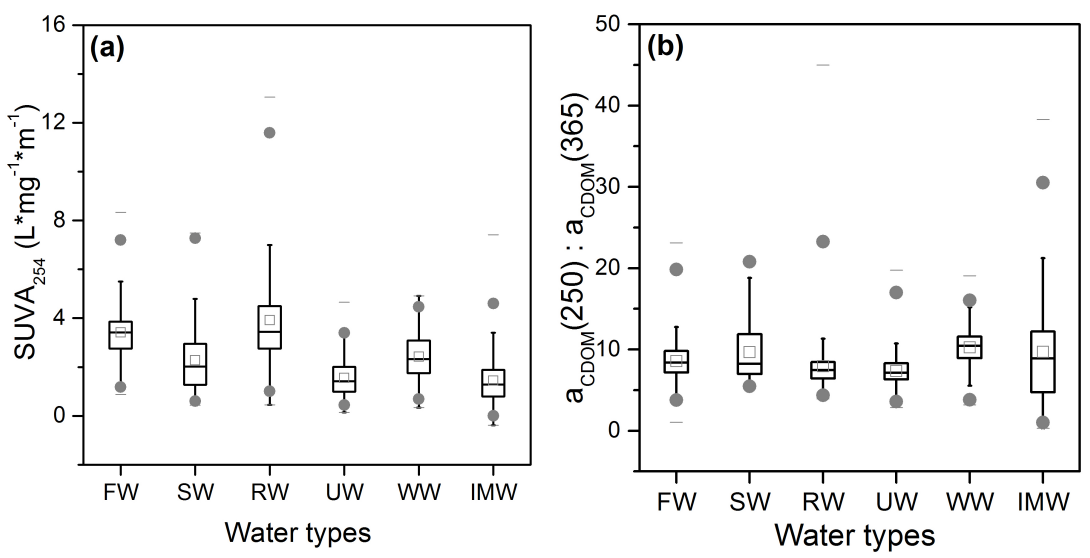

Figure 7. Comparison of (a) $\mathrm{SUVA}_{254}$ and (b) $M$ values $\left(a_{\mathrm{CDOM}}(250) / a_{\mathrm{CDOM}}(365)\right)$ to various types of inland waters. FW, fresh lake water; SW, saline lake water; RW, river or stream water; UW, urban water; WW, ice-covered waters from Northeast China; and IMW, ice melt waters from Northeast China.

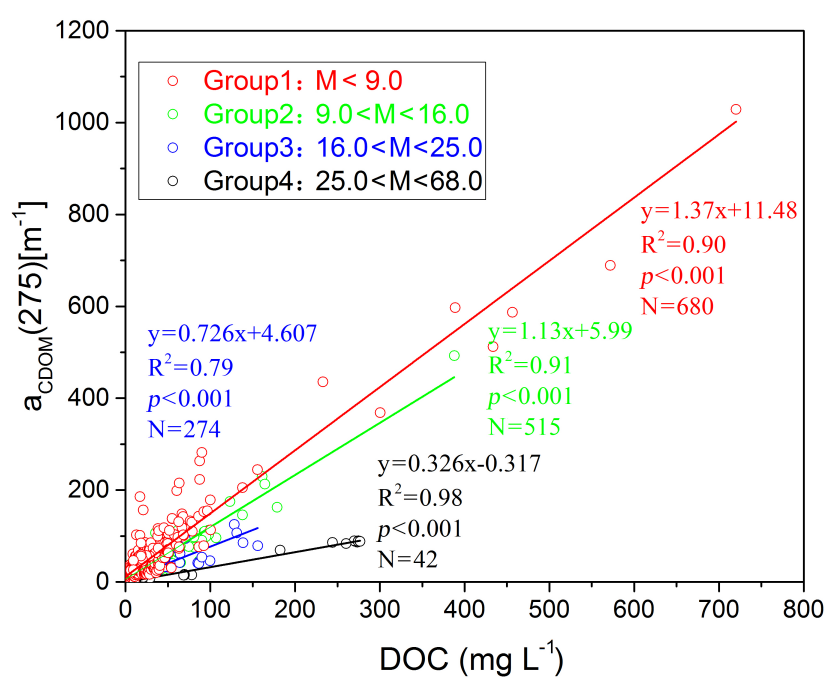

Figure 8. Relationships between DOC and $a_{\mathrm{CDOM}} 275$ sorted by $M$ $\left(a_{\mathrm{CDOM}}(250) / a_{\mathrm{CDOM}}(365)\right)$ values, Group 1: $M<9.0$; Group 2: $9.0<M<16.0$; Group 3: $16.0<M<25.0$; and Group 4: $25.0<$ $M<68.0$.

ies (Zhang et al., 2010; Zhou et al., 2016). Comparatively, fresh waters in Northeast and North China revealed larger regression slopes (Table 3). Waters in Northeast China are surrounded by forest, wetlands, and grassland and therefore they generally exhibited a high proportion of colored fractions of DOC. Further, soils in Northeast China are rich in organic carbon, which may also contribute to high concentrations of DOC and CDOM in waters in this region (Jin et al., 2016; Zhao et al., 2016a). Compared with waters in East and South China, waters in Northeast China showed less algal bloom due to the low temperature; thus, autochthonous CDOM was less present in waters in Northeast China (Song et al., 2013; Zhao et al., 2016a). As suggested by Brezonik et al. (2015) and Cardille et al. (2013), CDOM in the eutrophic waters or those with very short resident time may show seasonal variation due to algal bloom or hydrological variability, while CDOM in some oligotrophic lakes or those with long resident times may show a stable pattern.

As shown in Fig. 3b, a smaller regression slope is revealed between DOC and $a_{\mathrm{CDOM}}(275)$ for saline waters, indicating a less colored portion of DOC was present in waters in semiarid to arid regions. This is especially true for these closed lakes with enhanced photochemical processes, enhanced by longer residence times and strong solar radiation (Spencer et al., 2012; Song et al., 2013; Wen et al., 2016). The findings highlight the difference for the relationship between CDOM and DOC; thus, different regression models should be established to accurately estimate DOC in waters through linking with CDOM absorption, particularly for fresh and saline waters that show different specific absorption coefficients (Song et al., 2013; Cardille et al., 2013; Brezonik et al., 2015).

DOC concentration is strongly associated with hydrological conditions (Neff et al., 2006; Ågren et al., 2007; Yu et al., 2016). The relationships between CDOM and DOC in river and stream waters are very variable due to the hydrological variability and catchment features (Ågren et al., 2010; Spencer et al., 2012; Ward et al., 2013; Lee et al., 2015; Zhao et al., 2017). As shown in Fig. 4, the relationship between river flows and DOC is rather complicated, which is mainly caused by the land use, soil properties, relief, slope, the proportion of wetlands and forest, climate, and hydrology of the catchments (Neff et al., 2006; Sobek et al., 2007; Spencer et al., 2012; Zhou et al., 2016), with additional influences by sewage discharge into rivers. The close relationship for head waters with its higher regression slope value (Fig. 5a) is mainly attributed to the fact that the DOC and CDOM were fresh and less disturbed by pollution from anthropogenic activities (Spencer et al., 2012; Shao et al., 2016). However, both point-source and non-point-source pollution complicated the relationship between DOC and DOM (Fig. 5c). 

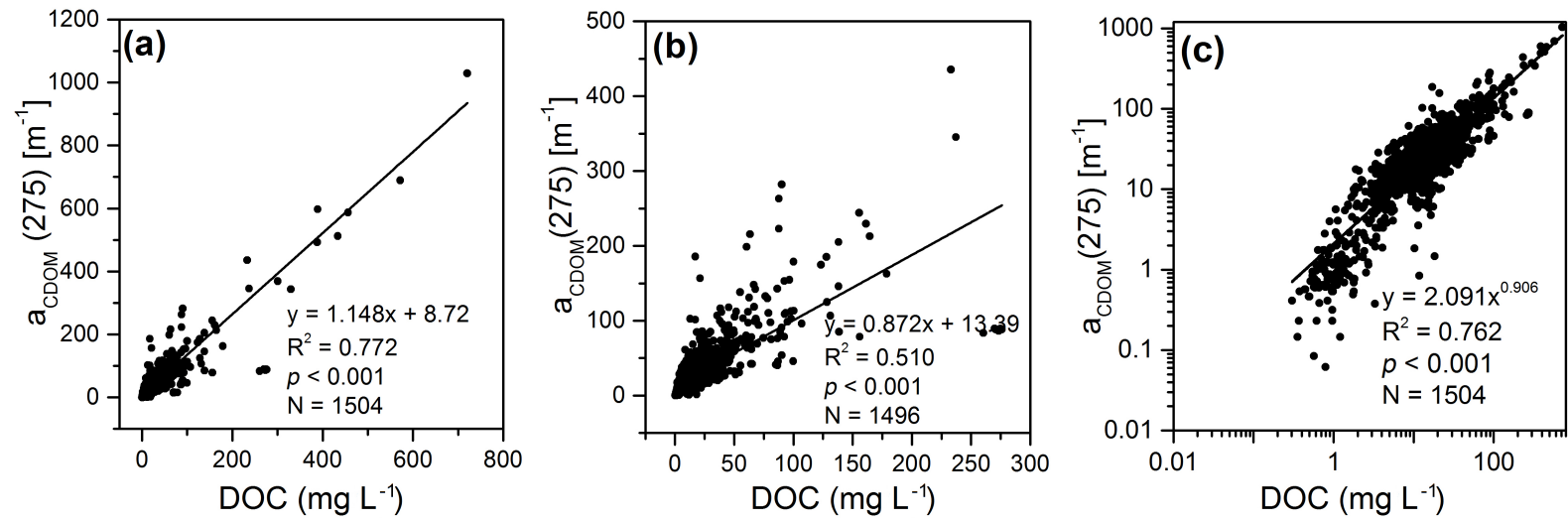

Figure 9. The relationships between $a_{\mathrm{CDOM}}$ (275) and DOC concentrations. (a) Regression model with pooled dataset, (b) regression model with DOC concentration less than $300 \mathrm{mg} \mathrm{L}^{-1}$, and (c) regression model with power fitting function based on a log-log scale.

\subsection{Regression models based on CDOM grouping}

As observed in Fig. 3, the regression slopes (range: 0.33 to $\sim 3.01)$ for the relationship between DOC and $a_{\mathrm{CDOM}}(275)$ varied significantly. The CDOM absorption coefficient is affected by its components and aromaticity; thus, the $M$ values are used to classify CDOM into different groups, which turns out to be an effective approach for improving regression models (Fig. 8) between DOC and $a_{\mathrm{CDOM}}$ (275). It also should be highlighted that group 4 (Fig. 8) is mainly from saline lakes (samples from embedded diagram in Fig. 3b); thus, the regression model slope is extremely low. From the regression model with pooled data, it can also be seen that a relatively accurate regression model for CDOM vs. DOC can be achieved with data collected in inland waters on a global scale (Sobek et al., 2007), which might be helpful in quantifying DOC through linking with CDOM absorption, and the latter parameter can be estimated from remote-sensing data (Zhu et al., 2011; Kuster et al., 2015). Comparing Fig. 8 and Fig. 9b, it also should be noted that some of the saline waters with extremely low CDOM absorption efficiency (group 4 in Fig. 8) should be divided into different groups to achieve an accurate DOC regression model through CDOM absorption.

\section{Conclusions}

Based on the measurement of CDOM absorption and DOC laboratory analysis, we have systematically examined the relationships between CDOM and DOC in various types of waters in China. This investigation showed that CDOM absorption varied significantly. River waters and fresh lake waters exhibited high CDOM absorption values and specific CDOM absorption $\left(\mathrm{SUVA}_{254}\right)$. In contrast, saline lakes illustrated low $\mathrm{SUVA}_{254}$ values probably due to the long residence times and strong photobleaching effects on waters in the semi-arid regions.
The current investigation indicated that the relationships between CDOM absorption and DOC varied remarkably by showing highly varied regression slopes in various types of waters. Head river water generally exhibits larger regression slope values, while rivers affected by anthropogenic activities show lower slope values. Saline water generally reveals small regression slope due to the photobleaching effect in the semiarid or arid region, combined with longer residence time. The accuracy of the regression model between $a_{\mathrm{CDOM}}$ (275) and DOC was improved when CDOM absorptions were divided into different sub-groups according to $M$ values. Our finding highlights that remote-sensing models for DOC estimation based on the relationship between CDOM and DOC should consider water types or cluster waters into several groups according to their absorption features.

Data availability. The data used in the preparation of this paper will be accessible to the public after the National Key Research and Development Project (no. 2016YFB0501502) financed by the Ministry of Science and Technology of the People's Republic of China has finished in 2021.

The Supplement related to this article is available online at https://doi.org/10.5194/hess-21-5127-2017supplement.

Competing interests. The authors declare that they have no conflict of interest.

Acknowledgements. The authors would like to thank financial support from the National Key Research and Development Project (no. 2016YFB0501502), Natural Science Foundation of China (nos. 41471290 and 41730104), and the "One Hundred Talents" Program from the Chinese Academy of Sciences granted to Kaishan Song. Thanks are also extended to all the staff and students 
for their efforts in field data collection and laboratory analysis, and Hong Yang to review and polish the English language. The authors are greatly indebted to associate editor Christian Stamm and the referees from both the previous and the current versions of the paper for their very valuable comments that greatly strengthened this paper.

\section{Edited by: Christian Stamm}

Reviewed by: Piotr Kowalczuk and one anonymous referee

\section{References}

Ågren, A., Buffam, I., Jansson, M., and Laudon, H.: Importance of seasonality and small streams for the landscape regulation of dissolved organic carbon export, J. Geophys. Res., 112, G03003, https://doi.org/10.1029/2006JG000381, 2007.

Ågren, A., Haei, M., Köhler, S. J., Bishop, K., and Laudon, H.: Regulation of stream water dissolved organic carbon (DOC) concentrations during snowmelt; the role of discharge, winter climate and memory effects, Biogeosciences, 7, 2901-2913, https://doi.org/10.5194/bg-7-2901-2010, 2010.

APHA/AWWA/WEF: Standard Methods for the Examination of Water and Wastewater, American Public Health Association, Washington, DC, 1998.

Arrigo, K. R., Mock, T., and Lizotte, M. P.: Primary producers and sea ice, In: Sea Ice, second Edition, edited by: Thomas, D. N., and Dieckmann, G. S., Wiley-Blackwell, Oxford, UK, 283-326, 2010.

Babin, M., Stramski, D., Ferrari, G. M., Claustre, H., Bricaud, A., Obolensky, G., and Hoepffner, N.: Variations in the light absorption coefficients of phytoplankton, nonalgal particles, and dissolved organic matter in coastal waters around Europe, J. Geophys. Res., 108, 3211, 2003.

Belzile, C., Gibson, J. A. E., and Vincent, W. F.: Colored dissolved organic matter and dissolved organic carbon exclusion from lake ice: implications for irradiance transmission and carbon cycling, Limnol. Oceanogr., 47, 1283-1293, 2002.

Binding, C. E., Jerome, J. H., Bukata, R. P., and Booty, W. G.: Spectral absorption properties of dissolved and particulate matter in Lake Erie, Remote Sens. Environ., 112, 1702-1711, 2008.

Brezonik, P. L., Olmanson, L. G., Finlay, J. C., and Bauer, M. E.: Factors affecting the measurement of CDOM by remote sensing of optically complex inland waters, Remote Sens. Environ., 157, 199-215, 2015.

Bricaud, A., Morel, A., and Prieur, L.: Absorption by dissolved organic matter of the sea (yellow substance) in the UV and visible domains, Limnol. Oceanogr., 26, 43-53, 1981.

Cardille, J. A., Leguet, J. B., and del Giorgio, P.: Remote sensing of lake CDOM using noncontemporaneous field data, Can. J. Remote Sens., 39, 118-126, 2013.

Chen, R. F., Bissett, P., Coble, P., Conmy, R., Gardner, G. B., Moran, M. A., Wang, X. C., Wells, M. L., Whelan, P., and Zepp, R. G.: Chromophoric dissolved organic matter (CDOM) source characterization in the Louisiana Bight, Mar. Chem., 89, 257-272, 2004.

Curtis, P. J. and Adams, H. E.: Dissolved organic matter quantity and quality from freshwater and saltwater lakes in east-central Alberta, Biogeochemistry, 30, 59-76, 1995.
De Haan, H.: Solar UV-light penetration and photodegradation of humic substances in peaty lake water, Limnol. Oceanogr., 38, 1072-1076, 1993.

De Haan, H. and De Boer, T.: Applicability of light absorbance and fluorescence as measures of concentration and molecular size of dissolved organic carbon in humic Lake Tjeukemeer, Water Res., 21, 731-734, 1987.

Fichot, C. G. and Benner, R.: A novel method to estimate DOC concentrations from CDOM absorption coefficients in coastal waters, Geophys. Res. Lett., 38, L03610, https://doi.org/10.1029/2010GL046152, 2011.

Findlay, S. E. G. and Sinsbaugh, R. L.: Aquatic Ecosystems Interactivity of Dissolved Organic Matter, Academic Press, San Diego, CA, USA, 2003.

Gonnelli, M., Vestri, S., and Santinelli, C.: Chromophoric dissolved organic matter and microbial enzymatic activity. A biophysical approach to understand the marine carbon cycle, Biophysical Chemistry, 182, 79-85, 2013.

Helms, J. R., Stubbins, A., Ritchie, J. D., Minor, E. C., Kieber, D. J., and Mopper, K.: Absorption spectral slopes and slope ratios as indicators of molecular weight, source, and photobleaching of chromophoric dissolved organic matter, Limnol. Oceanogr., 53, 955-969, 2008.

Huang, C. C., Li, Y. M., Yang, H., Li, J. S., Chen, X., Sun, D. Y., Le, C. F., Zou, J., and Xu, L. J.: Assessment of water constituents in highly turbid productive water by optimization bio-optical retrieval model after optical classification, J. Hydrol., 519, 15721583, 2014.

Jaffé, R., McKnight, D., Maie, N., Cory, R., McDowell, W. H., and Campbell, J. L.: Spatial and temporal variations in DOM composition in ecosystems: the importance of long-term monitoring of optical properties, J. Geophys. Res., 113, G04032, https://doi.org/10.1029/2008JG000683, 2008.

Jeffrey, S. W. and Humphrey, G. F.: New spectrophotometric equations for determining chlorophylls $a, b, c_{1}$, and $c_{2}$ in higher plants, algae and natural phytoplankton, Biochem. Physiol. Pfl., 167, 191-194, 1975.

Jin, X. L., Du, J., Liu, H. J., Wang, Z. M., and Song, K. S.: Remote estimation of soil organic matter content in the Sanjiang Plain, Northeast China: the optimal band algorithm vs. the GRA-ANN model, Agr. Forest Meteorol., 218, 250-260, 2016.

Kowalczuk, P., Zablocka, M., Sagan, S., and Kulinski, K.: Fluorescence measured in situ as a proxy of CDOM absorption and DOC concentration in the Baltic Sea, Oceanologia, 52, 431-471, 2010.

Kutser, T., Verpoorter, C., Paavel, B., and Tranvik, L. J.: Estimating lake carbon fractions from remote sensing data, Remote Sens. Environ., 157, 138-146, 2015.

Le, C. F., Hu, C. M., Cannizzaro, J., and Duan, H. T.: Long-term distribution patterns of remotely sensed water quality parameters in Chesapeake Bay, Estuar. Coast. Shelf S., 128, 93-103, 2013.

Lee, E.-J., Yoo, G.-Y., Jeong, Y., Kim, K.-U., Park, J.-H., and Oh, N.-H.: Comparison of UV-VIS and FDOM sensors for in situ monitoring of stream DOC concentrations, Biogeosciences, 12, 3109-3118, https://doi.org/10.5194/bg-12-3109-2015, 2015.

Lee, Z. P., Carder, K. L., and Arnone, R. A.: Deriving inherent optical properties from water color: a multiband quasi-analytical algorithm for optically deep waters, Appl. Optics, 41, 5755-577, 2002. 
Miller, W. L. and Zepp, R. G.: Photochemical production of dissolved inorganic carbon from terrestrial organic matter: significance to the oceanic organic carbon cycle, Geophys. Res. Lett., 22, 417-420, 1995.

Neff, J. C., Finlay, J. C., Zimov, S. A., Davydov, S. P., Carrasco, J. J., Schuur, E. A. G., and Davydova, A. I.: Seasonal changes in the age and structure of dissolved organic carbon in Siberian rivers and streams, Geophys. Res. Lett., 33, L23401, https://doi.org/10.1029/2006GL028222, 2006.

Pekel, J. F., Cottam, A., Gorelick, N., and Belward, A. S.: Highresolution mapping of global surface water and its long-term changes, Nature, 540, 417-422, 2016.

Raymond, P. A., Hartmann, J., Lauerwald, R., Sobek, S., McDonald, C., Hoover, M., Butman, D., Striegl, R., Mayorga, E., Humborg, C., Kortelainen, P., Durr, H., Meybeck, M., Ciais, P., and Guth, P.: Global carbon dioxide emissions from inland waters, Nature, 503, 355-359, 2013.

Reche, I., Pace, M., and Cole, J. J.: Relationship of trophic and chemical conditions to photobleaching of dissolved organic matter in lake ecosystems, Biogeochemistry, 44, 529-280, 1999.

Shao, T. T., Song, K. S., Du, J., Zhao, Y., Ding, Z., Guan, Y., Liu, L., and Zhang, B.: Seasonal variations of CDOM optical properties in rivers across the Liaohe Delta, Wetlands, 36, 181-192, 2016.

Shi, K., Li, Y. M., Li, L., Lu, H., Song, K. S., Liu, Z., Xu, Y., and Li, Z.: Remote chlorophyll $a$ estimates for inland waters based on a cluster-based classification, Sci. Total Environ., 444, 1-15, 2013.

Spencer, R. G. M., Stubbins, A., Hernes, P. J., Baker, A., Mopper, K., Aufdenkampe, A. K., Dyda, R. Y., Mwamba, V. L., Mangangu, A. M., Wabakanghanzi, J. N., and Six, J.: Photochemical degradation of dissolved organic matter and dissolved ligninphenols from the Congo River, J. Geophys. Res., 114, G03010, https://doi.org/10.1029/2009JG000968, 2009.

Spencer, R. G. M., Butler, K. D., and Aiken, G. R.: Dissolved organic carbon and chromophoric dissolved organic matter properties of rivers in the USA, J. Geophys. Res., 117, G03001, https://doi.org/10.1029/2011JG001928, 2012.

Sobek, S., Tranvik, L. J., Prairie, Y. T., Kortelainen, P., and Cole, J. J.: Patterns and regulation of dissolved organic carbon: an analysis of 7500 widely distributed lakes, Limnol. Oceanogr., 52, 1208-1219, 2007.

Song, K. S., Zang, S. Y., Zhao, Y., Li, L., Du, J., Zhang, N. N., Wang, X. D., Shao, T. T., Guan, Y., and Liu, L.: Spatiotemporal characterization of dissolved carbon for inland waters in semihumid/semi-arid region, China, Hydrol. Earth Syst. Sci., 17, 4269-4281, https://doi.org/10.5194/hess-17-4269-2013, 2013.

Stedmon, C. A., Thomas, D. N., Papadimitriou, S., Granskog, M. A., and Dieckmann, G. S.: Using fluorescence to characterize dissolved organic matter in Antarctic sea ice brines, J. Geophys. Res., 116, G03027, https://doi.org/10.1029/2011JG001716, 2011.

Tian, Y. Q., Ouyang, H., Xu, X. L., Song, M. H., and Zhou, C. P.: Distribution characteristics of soil organic carbon storage and density on the Qinghai-Tibet Plateau, Acta Pedologica Sinica, 45, 933-942, 2008.

Tong, Y. D., Zhang, W., Wang, X. J., Couture, R. M., Larssen, T., Zhao, Y., Li, J., Liang, H. J., Liu, X. Y., Bu, X. G., He, W., Zhang, Q. G., and Lin, Y.: Decline in Chinese lake phosphorus concen- tration accompanied by shift in sources since, 2006, Nat. Geosci., 10, 507-511, 2017.

Tranvik, L. J., Downing, J. A., Cotner, J. B., Loiselle, S. A., Striegl, R. G., Ballatore, T. J., Dillon, P., Finlay, K., Fortino, K., Knoll, L. B., Kortelainen, P. L., Kutser, T., Larsen, S., Laurion, I., Leech, D. M., McCallister, S. L., McKnight, D. M., Melack, J. M., Overholt, E., Porter, J. A., Prairie, Y., Renwick, W. H., Roland, F., Sherman, B. S., Schindler, D. W., Sobek, S., Tremblay, A., Vanni, M. J., Verschoor, A. M., Wachenfeldt, E., and Weyhenmeyer, G. A.: Lakes and reservoirs as regulators of carbon cycling and climate, Limnol. Oceanogr., 54, 2298-2314, 2009.

Vantrepotte, V., Loisel, H., Dessailly, D., and Mériaux, X.: Optical classification of contrasted coastal waters, Remote Sens. Environ., 123, 306-323, 2012.

Verpoorter, C., Kutser, T., Seekell, D. A., and Tranvik, L. J.: A global inventory of lakes based on high-resolutionsatellite imagery, Geophys. Res. Lett., 41, 6396-6402, 2014.

Vodacek, A., Blough, N. V., Degrandpre, M. D., Peltzer, E. T., and Nelson, R. K.: Seasonal variation of CDOM and DOC in the Middle Atlantic Bight: terrestrial inputs and photooxidation, Limnol. Oceanogr., 42, 674-686, 1997.

Ward Jr, J. H.: Hierarchical grouping to optimize an objective function, J. Am. Stat. Assoc., 58, 236-244, 1963.

Ward, N. D., Keil, R. G., Medeiros, P. M., Brito, D. C., Cunha, A. C., Dittmar, T., Yager, P. L., Krusche, A. V., and Richey, J. E.: Degradation of terrestrially derived macromolecules in the Amazon River, Nat. Geosci., 6, 530-533, 2013.

Weishaar, J. L., Aiken, G. R., Bergamaschi, B. A., Fram, M. S. Fugii, R., and Mopper, K.: Evaluation of specific ultraviolet absorbance as an indicator of the chemical composition and reactivity of dissolved organic carbon, Environ. Sci. Technol., 37, 47024708, 2003.

Wen, Z. D., Song, K. S., Zhao, Y., Du, J., and Ma, J. H.: Influence of environmental factors on spectral characteristics of chromophoric dissolved organic matter (CDOM) in Inner Mongolia Plateau, China, Hydrol. Earth Syst. Sci., 20, 787-801, https://doi.org/10.5194/hess-20-787-2016, 2016.

Williamson, C. E. and Rose, K. C.: When UV meets fresh water, Science, 329, 637-639, 2010.

Yang, H., Xie, P., Ni, L., and Flower, R. J.: Pollution in the Yangtze, Science, 337, 410-410, 2012.

Yang, H., Andersen, T., Dörsch, P., Tominaga, K., Thrane, J.-E., and Hessen, D. O.: Greenhouse gas metabolism in Nordic boreal lakes, Biogeochemistry, 126, 211-225, 2015.

Yu, Q., Tian, Y, Q., Chen, R. F., Liu, A., Gardner, G. B., and Zhu, W. N.: Functional linear analysis of in situ hyperspectral data for assessing CDOM in rivers, Photogramm. Eng. Rem. S., 76, 1147-1158, 2010.

Yu, X. L., Shen, F., and Liu, Y. Y.: Light absorption properties of CDOM in the Changjiang (Yangtze) estuarine and coastal waters: an alternative approach for DOC estimation, Estuar. Coast. Shelf S., 181, 302-311, 2016.

Zhang, Y. L., Zhang, E. L., Yin, Y., Van Dijk, M. A., Feng, L. Q., Shi, Z. Q., Liu, M. L., and Qin, B. Q.: Characteristics and sources of chromophoric dissolved organic matter in lakes of the Yungui Plateau, China, differing in trophic state and altitude, Limnol. Oceanogr., 55, 2645-2659, 2010.

Zhao, Y., Song, K., Wen, Z., Li, L., Zang, S., Shao, T., Li, S., and $\mathrm{Du}, \mathrm{J}$.: Seasonal characterization of CDOM for lakes in semi- 
arid regions of Northeast China using excitation-emission matrix fluorescence and parallel factor analysis (EEM-PARAFAC), Biogeosciences, 13, 1635-1645, https://doi.org/10.5194/bg-131635-2016, 2016a.

Zhao, Y., Song, K. S., Li, S. J., Ma, J. H., and Wen, Z. D.: Characterization of CDOM from urban waters in Northern-Northeastern China using excitation-emission matrix fluorescence and parallel factor analysis, Environ. Sci. Pollut. R., 23, 15381-15394, 2016b.

Zhao, Y., Song, K. S., Shang, Y. X., Shao, T. T., Wen, Z. D., and Lv, L. L.: Characterization of CDOM of river waters in China using fluorescence excitation-emission matrix and regional integration techniques, J. Geophys. Res.-Biogeo., 122, 1940-1953, https://doi.org/10.1002/2017JG003820, 2017.
Zhou, Y., Zhang, Y., Jeppesen, E., Murphy, K. R., Shi, K., Liu, M., Liu, X., and Zhu, G: Inflow rate-driven changes in the composition and dynamics of chromophoric dissolved organic matter in a large drinking water lake, Water Res., 100, 211-221, 2016.

Zhu, W., Yu, Q., Tian, Y. Q., Chen, R. F., and Gardner, G. B.: Estimation of chromophoric dissolved organic matter in the Mississippi and Atchafalaya river plume regions using above-surface hyperspectral remote sensing, J. Geophys. Res.-Oceans, 116, C02011, https://doi.org/10.1029/2010JC006523, 2011.

Zhu, W. N., Yu, Q., Tian, Y. Q., Becker, B. L., Zheng, T., and Carrick, H. J.: An assessment of remote sensing algorithms for colored dissolved organic matter in complex freshwater environments, Remote Sens. Environ., 140, 766-778, 2014. 